chæta; Dr. H. E. Jordan gives an account of the structure of the striped muscle of Limulus, and also traces the embryonic history of the germ-cells of the loggerhead turtle from the emigration of the primordial germ-cells from the yolk-sac endoderm to their arrival in their final positions.

\section{RESEARCH PAPERS FROM THE UNIVERSITY OF SYDNEY.}

THE University of Sydney has recently issued (for private circulation) several volumes of reprints of papers by members of its staff and by its research students during the period rgog-r6. It is clear that the University is doing its duty in contributing to scientific progress, and in training its best students in the methods of research. Thus in vol. A we have a list of upwards of sixty papers (twenty of which are included in this volume) ranging over the subjects of mathematics, physics, chemistry, agriculture, and engineering; and although, of course, they are of unequal value in the eyes of an expert, they are all concerned with genuine scientific problems, the solution of which means something more than a mere class exercise. One paper is of an exceptional kind, as dealing with a chapter of mathematical history. 'This is Prof. H. S. Carslaw's Napier commemorative lecture, which gives a clear and interesting account of what Napier's logarithms were (even yet this is often wrongly stated), and of the way in which they were calculated. The other papers are technical, and we must content ourselves with noting those in the complete list which obviously deal with specially Australian matters. These are: (I) Two papers on superannuation and pension funds; ; 2 one on the teaching of mathematics in Australia; (3) one on Australian coalfields and collieries; (4) one on the Hargreaves goldfield, N.S.W. None of these, however, appear in this volume, probably because the stock has been exhausted.

An interesting record of the activities in research of the anatomists and biologists of the University is contained in vol. i., series B. Unfortunately the volume is by no means complete, for of the fifty-seven papers which have actually been published during the period covered (1909-16) only twenty-eight are represented. This, however, is five more than we are led to expect from the table of contents, which is to that extent inaccurate. These papers represent the original research of a dozen different authors, and naturally range over a wide field, from pathological anatomy to zoogeography. The most distinctively Australian contributions are those dealing with the fauna of the great island-continent. The botanical side of biological science is but slightly represented, though we may expect to see a great advance in this direction now that a separate department of botany has been established in the University. A good many of the papers were originally published in English journals, and are already well known to workers in this country. Of the remainder, the Proceedings of the Linnean Society of New South Wales furnish a very large proportion. We may direct special attention to Mr. E. F. Hallmann's "Revision of the Monaxonid Sponges described as new in Lendenfeld's Catalogue of Sponges in the Australian Museum." Such a revision was greatly needed, for the catalogue in question is a singularly unsatisfactory piece of work. Mr. R. J. Tillyard's papers on dragonflies constitute a conspicuous feature of the volume and a very notable contribution to the study of this group of insects, which is dealt with from the different points of view of systematic zoology, geographical distribution, and physiology. We note that Messrs. Hallmann and Tillyard are, or were, both NO. 2509 , VOL. IOO]
Linnean Mackay fellows in zoology. These fellowships have done much to promote the study of zoology in a country where an immense amount of work still remains to be done before our knowledge of the fauna can be placed upon a really satisfactory footing. The issue of this volume coincides with the retirement of Prof. Haswell from the chair of zoology, which he has so long held. He himself contributes four memoirs to the collection, and we hope that his valuable researches in Australian zoology will long be continued.

Series B, vol. ii., is concerned with geology, pathology, and physiology, the first-named science occupying by far the greatest portion. The papers include a series by W. N. Benson on the "Great Serpentine Belt of New South Wales," where the perennial subject of the connection between radiolarian cherts and pillow-lavas comes up for discussion in the case of rocks of Middle Devonian age. The association of frequent casts of Lepidodendron with radiolaria has raised interesting physiographic questions. The alluvial deposits of Copeton, N.S.W., containing tinstone and diamonds, have been worked since 1873 , and $\mathrm{Mr}$. L. A. Cotton has recorded (I9I4) a diamond in a quartz-dolerite of the district. He regards the basic magma as the true matrix, and does not suggest a derivation from underlying rocks. Prof. Edgeworth David has stimulated so much of the geological work in the University of Sydney that his address to the Australasian Association in I9I3 seems very fittingly included in this volume. It deals with the influence of an Antarctic continent, varying in dimensions in geological time, on the climate of Australia, and attributes the cold Permo-Carboniferous conditions to the immense extension of land in the south of the southern hemisphere. Among the physiological papers is one of importance to chemists, by Mr. H. Wardlaw, on "The Accuracy of Neumann's Method for the Estimation of Phosphorus." Though this author's work has been largely concerned with milk, of human or other origin, he has found time for a specially Australian study on the variations of temperature in Echidna.

\section{THE SURVEY OF INDIA.}

THE Indian Survey Report for $1915-16$ contains nothing of special interest either in the department of exploration or in that of science, but it is a good record of solid work carried out under the direction of Sir Sidney Burrard, curtailed in certain branches by the exigencies of war service, but on the whole a most satisfactory report. The progress made in the topographical mapping of the huge area of India in the ten years preceding I9I6 shows that between onefourth and one-fifth of that area has been completed on various scales and by various methods up to date, but one is left in doubt as to the comparative values of the revision necessary in the mapping of an older date than 1905. The whole of India (or very nearly the whole) must have been mapped by then, on scales which are much the same as those now adopted for various classes of land area. Surely very little revision is necessary in those barren areas (within the frontier) that were mapt ed on the smaller scales. On the other hand, much of the $x$ in. per mile mapping must have required actual re-survey. The area remaining to be mapped amounts to $\mathrm{I} \cdot 382767$ square miles (or thereabouts?), so the Survey of India has still a career before it.

It is worthy of note that thirty-six "Imperial" officers have been withdrawn for active service, and that of that number no fewer than seven have already laid down their lives for their country. A survey party has been attached to the forces in Mesopotamia, and the result of its work will be of special interest, but otherwise no trans-frontier geo- 
graphical work is reported. The trigonometrical branch has necessarily been curtailed in its activities, the scientific work of that branch (astronomical, magnetic, and tidal) making un its chief record, with but little reference to the extension of geodetic triangulation. In the department of map publication there has been great activity, the total number of maps published $(626,329)$ during the year being in excess of that of the year previous.

T. H. H.

\section{MODERN DEVELOPMENTS OF THE GAS INDUSTRY.}

O WING to sudden illness, Mr. W. B. Worthington asked at the end of October to be released from the duties of the presidency of the Institution of Civil Engineers. Mr. Harry Jones, who has been elected to succeed him, delivered the presidential address before the institution on November $6 . \mathrm{Mr}$. Jones is the chairman of the High Explosives Committee, of which Lord Moulton is president, and is the first member of the gas engineering profession who has occupied the chair at the Institution of Civil Engineers. In his address he dealt with modern developments in gas practice, how far the practice has been making itself useful during the war, the fresh prospects it has in the coming time of peace, and, finally, the special qualification of the gas engineer and the work he has to do. Subjoined are extracts from the address.

There has come about in the work of the gas engineer an entire revolution. We used to be called "gas light companies," and the ancient Act of Parliament used to speak of "furnishing a luminous vapour." The revolution that I speak of is in the fact that the use of gas for direct lighting has become almost extinct, and there has been an enormous development of gas as pure fuel, both for domestic and trade purposes, as well as for motor-cars. So extensive has the growth been that it is estimated that, allowing for the use of incandescent mantle burners, not 5 per cent. of the whole output is now used for direct illumination.

The fuel and engine use varies as the towns are more or less industrial, but evidence is not wanting that that also is growing very rapidly. For instance, in the East of London the Royal Mint melts the whole of the coinage by gas furnaces, and Messrs. Rothschild's large refinery uses the same means of smelting. It is remarkable that the gas company which furnishes that supply, having made fuses for war purposes, was found to have by its furnaces melted the metal with such good effect as to produce an alloy so superior that the company has been specially asked to smelt metals on a large scale for the Munitions Department, and is now carrying out a considerable amount of smelting for that department, and you may be interested to learn that this is entirely done by women operators.

Sir Robert Hadfield has stated that in his Sheffield works he uses as much as 500,000,000 cub. ft. of gas per annum for smelting and metallurgical purposes, which represents the output of 45,000 tons of coal. Mr. Hanbury. Thomas, the manager of the Sheffield Gas Company, has stated that his company has no fewer than 642 furnaces, consuming $372,000,000$ cub. ft. of gas, at work in his district, while 15,116 h.p. gas engines consume $780,000,000 \mathrm{cub}$. ft. From Birmingham. Manchester, Glasgow, and, indeed, from all the manufacturing towns, we hear similar statements. For such purposes the cleanliness, flexibility, intensity of heat, and control of gas fuel must be very great considerations indeed. The effect of all these uses of gas has been to level the load factor and to remove the NO. 2509 , VOL. IOO] maximum demand peak from night-time in midwinter, which was formerly the time when people wanted special light, and often some heat; but to-day the midday cooking hour on a summer Sunday forms the peak in the industrial suburbs of London. There is no hour which demands so much gas as that particular hour on a July Sunday.

An important result of these extended uses of gas appliances has been their ready applicability to the rapid furnishing of munitions on emergency. Acknowledgment is due to makers of furnaces and stove plants for the aptitude and energy shown by them in forcing their output to meet the stress of war, in face of scarcity of materials and labour. Moreover, they have devised a great variety of useful and ingenious plant for facilitating processes of all kinds and for speeding up output, and these have been eagerly accepted by those engaged on munition works.

But, quite apart from general service of this kind, a special direct supply of high explosive material was effectively furnished at short notice in adequate quantities to the War Department, and, although I must not enlarge upon this, I have obtained Lord Moulton's permission to quote to you the full and generous recognition he has given publicly to these services of the gas industry. Among other complimentary and generous expressions he has stated:- "Without the direct aid of the gas industry, and, further than that, the assistance and the knowledge which have been acquired by those who devote their lives to it, it would have been perfectly impossible for this country to have waged the campaign of the last three years, or even for any but a trifling time resist the overwhelming floods of enemies that were poured upon it. When I first was asked to take charge of the manufacture and production of explosives, it took me but a few days to realise my absolute dependence on your great industry. My appeal to the leaders to assist me was made immediately. . . The response has been so splendid that we have become, I might almost say, affluent where I expected nothing but pauperism, and gradually we have seen ourselves creeping up to an equality with the supplies that our enemies have been piling up year after year in anticipation of a war that they intended to bring upon us, until now I think that our anxiety in this department, which at first was probably the keenest anxiety of all, has passed away through your assistance."

The explanation of this graceful acknowledgment is that at the time the appeal was made there was in the hands of the gas engineer neither a process nor plant for the recovery of one special requirement. For the best process the plant foundations and housing wanted months for execution. But Dr. Carpenter found that by using our own tar as a solvent at a suitable temperature and diverting part of our existing plant from its normal use, the greater part of the recovery could be effected at once, and that, too, by gasworks below the scale justifying the special plant being erected. Lord Moulton sanctioned this departure, and within a fortnight some of us got going on the Carpenter process, and began to "deliver the goods," which were at that time very vital. So much has been needed since that we have mostly installed the more complete plant on large-scale works, but no profit at all is got out of this; moreover, the service of the chiefs of the staff for organising the co-operation of all the gas undertakings in this work has been furnished by the gas companies without anv charge whatever to the Government, and many other accommodations have been gratuitously afforded.

The extended number and varietv of processes arising in the prosecution of war service generally in the furnishing of munitions inevitably lead us to the consideration of how far these processes will help us in 